\title{
THE USE AND ABUSE OF PERFORMATIVE ARTS FOR RELIGION AND SOCIETY'
}

The objective of this article is to examine some of the discussions regarding performative arts (i.e. theatre) in Germany and the Baltic provinces in the $18^{\text {th }}$ century and to add theological-philosophical marginalia to those discussions.

During the Enlightenment period the role of art, its objectives and influence on both artists, and the public that shared in it, was frequently and readily discussed. Of course, the topic was not specific to the Enlightenment only - already Plato's dialogue The Republic called for a discussion concerning the benefits or harmfulness of poetry and theatre. ${ }^{2}$

But nevertheless let it be declared that, if the mimetic and dulcet poetry can show any reason for her existence in a well-governed state, we would gladly admit her, since we ourselves are very conscious of her spell. [...] And we would allow her advocates who are not poets but lovers of poetry to plead her cause in prose without metre, and show that she is not only delightful but beneficial to orderly government and all the life of man.

Plato's presentation of the problem essentially comprises the question of what a person's and well-governed city's ultimate goal could be, and

DOI: http: //dx.doi.org/10.12697/BJAH.2014.8.03

Translation by Juta Ristsoo.

The research was supported by the targeted financing project SF0180026s11 and the European Union through the European Regional Development Fund (Centre of Excellence CECT).

1 See also Jacques Barzun, The Use and Abuse of Art (Princeton: Princeton University Press, 1975), 3.

2 Plat. Rep. 607d: Plato, Plato in Twelve Volumes, Vols. 5 \& 6 trans. by Paul Shorey (Cambridge, MA: Harvard University Press, 1969). 
based thereupon, whether some activity can help achieve this goal, has no affect on it, or can even hinder the achievement of that goal. During classical antiquity, the self-evident final objective was eudaimonia - permanent wellbeing. According to Plato, this can only be achieved through governing of reason, and the activity of reason is summarised as an aspiration toward the Form of the Good (tou agathou idea) $)^{3}$. Thus, one can say that in The Republic Plato combines an individual's personal eudaimonia with society's wellbeing and makes both dependent on the sphere of eternal ideas. The Platonic Form of the Good, on which all other things depend, was interpreted already by early Christian apologists, such as Justin the Martyr and Clement of Alexandria, as referring to God. This path of reasoning became very influential in both Eastern and Western theology especially through the writings of Origen, Augustine of Hippo and Pseudo-Dionysius the Areopagite and stayed important through medieval and early modern period.

Also, most people in Enlightenment Europe continued to seek the ultimate goal of human life in religion. Yet, religion was no longer confined to the teachings and traditional rituals approved by the leading theologians of the Christian denominations - Pietists, as well as Enlighteners (based on their respective emphasis) declared that personally perceived faith or beliefs based on rational arguments had priority over church institutions. On one hand true piety was sought (Pietism) and on the other hand common foundations of all the world's religions were discussed (universal religion). The new trends that appeared during the German Enlightenment accused Orthodox Lutheranism, which had predominated during the $17^{\text {th }}$ century, of rigid dogmatism and a detachment from real life. As opposed to the emphasis on elite intellectual comprehension typical of medieval Catholicism and, in a certain sense, Lutheran orthodoxy, the goal for both religious and secular thinkers became egalitarian life-centred practical activity, which had the potential to aid in the promotion of general wellbeing. The basis for practical theology was established at the universities, emphasis was placed on differentiation between theoretical and practical philosophy, and the interest in and demand for practical education (e.g. Realschule) increased. The formation of the citizen class and appreciation of a bourgeois worldview, which gradually developed in $18^{\text {th }}$-century Germany, meant that the

3 Plat. Rep. 508e2-3. 
entire society paid greater attention to the questions related to whether one or another activity was beneficial.

In this context, a new identity also needed to be found for artistic activities, which, until the goals of society and religion were severed, was included in the same whole.

During antiquity clear boundaries between religious and secular activities were lacking. This understanding was also reflected in the various Greek and Latin names for (pagan) religion, which referred primarily to the performance of good practices and customs (threskeia, eusebeia, religio, pietas). ${ }^{4}$ In the Roman Empire, the emperor was also the pontifex maximus, the high priest, who was the embodiment of both political and religious power. Fidelity to Roman religion was the same as fidelity to the Roman emperor and vice versa. When Christianity became the state religion in the $4^{\text {th }}$ century, a similar combination of objectives developed, which, to a greater or lesser extent, continued until the modern period. A ruler in medieval and early modern Europe had a patriarchal obligation regarding the religion of his subjects (right of patronage, ius patronatus) and later, in the Protestant countries, the rulers also often served as the formal heads of the church (the king was also summus episcopus). ${ }^{5}$ Critics of such arrangement have existed throughout history among both clerics and laypersons. In the post-Reformation disorder, and especially due to the denominational splits of the $17^{\text {th }}$ century, this interrelation between confession and state became the topic of intense discussions. Can religious and secular power be combined, and should it be? In other words, is the activity that is beneficial to society also beneficial to the achievement of the goals of various denominations and vice versa? These discussions resulted in the state becoming to a lesser extent responsible for the salvation of all its citizens - religious quarrels were now often shifted away from the public sphere.

The place of art in society did go through similar shifts. In medieval Western philosophy and theology (most influentially in the writings of Gregory the Great and St. Thomas Aquinas), all images and $\operatorname{art}^{6}$ were

4 Garth Fowden, "Religious Communities," Late Antiquity: A Guide to the Postclassical World, ed. Glen Warren Bowersock, Peter Brown, and Oleg Grabar (Cambridge, MA: Harvard University Press, 1999), 82-106, 83.

5 See, e.g., Ralph Tuchtenhagen, Zentralstaat und Provinz im frühneuzeitlichen Nordosteuropa (Wiesbaden: Otto Harrassowitz Verlag, 2008), 106, 206.

6 Art is here considered in the wider sense of encompassing any creative activity regardless of the percieved artistic value of the end result. 
considered to be nearly synonymous with text. Art served mostly didactic, illustrative and instructive purposes, but it usually lacked any connection with sanctity - i.e. it had no participation in invisibility as it was theorized in the neoplatonic icon theology of the Eastern church. ${ }^{7} \mathrm{~A}$ central role in Western understanding of images and art was played by the mimetic nature of art, which had the task of providing depictions of events for the uneducated who could not experience them due to their lack of literacy (quod est clerico littera, hoc est laico pictura). ${ }^{8}$ Iohannes Beleth and Clairvaux Bernard also believe that monks who know how to read do not need to be surrounded by pictures and adornments. ${ }^{9}$ Since religion was one of the primary means of creating unity and identity in medieval Europe, it is understandable that medieval art - like medieval writing - was predominantly religious. In this way, art (both visual and auditory) became part of the public space, and its main goal was to deliver a religious and didactical message through pictures, architecture, theatrical performances.

In the $16^{\text {th }}$ century, widespread discussions seeking church reform occurred, which included the problem of images, and therefore, also performative arts. In the context of theological disputes, the question arises anew as to what role do images, processions and theatrical performances play in society and in the church. In other words, is visualisation an appropriate means for expressing church teaching to the illiterate? Is this activity beneficial, harmful or innocuous for religion? Since art, as an illustrative means of teaching the illiterate, had become widespread during the Middle Ages, then naturally, some of the reformers' criticism of the Catholic church was directed against these elucidations. Thus, images as such did not constitute a separate issue for the reformers, but were part of the general criticism of the church as a whole. These discussions were primarily related to what "face" the church, which was representative of holiness, should turn toward the believers, i.e. society.

7 Herbert L. Kessler, "Gregory the Great and Image Theory in Northern Europe during the Twelfth and Thirteenth Centuries", A Companion to Medieval Art: Romanesque and Gothic in Northern Europe, ed. Conrad Rudolph, Blackwell Companions to Art History 2 (Oxford: Blackwell, 2008), 152ff.

8 Iohannes Beleth, Summa de ecclesiasticis officiis, ed. H. Douteil, 1976, CC CM, 41A (Turnhout: Brepols Publishers), cap. 85.

9 Chrysogonus Waddell, "The Reform of the Liturgy from a Renaissance Perspective", Renaissance and Renewal in the Twelfth Century, ed. Robert Louis Benson, Giles Constable, and Carol Dana Lanham (Cambridge, MA: Harvard University Press, 1982), 97. 
In this regard, one can place the various attitudes toward art on a scale that ranges from rather favourable to decisively opposed.

Martin Luther and his supporters represented a moderate approach, which to a great extent, places art in the field of adiaphora, i.e. a sphere that is not directly mandated or forbidden by the Scriptures nor an activity required of the church for helping one's fellow-man. ${ }^{10}$ In a certain sense, if something was placed in the sphere of adiaphora it meant it was not considered significant and based thereon Luther's own criticism of art is not systematic and sometimes leaves the impression of being favourable to art. In questions related to the theatre, Luther also favours school drama as an appropriate form of teaching ${ }^{11}$ and in the case of fine art, calls for the sufferings of Christ to be shown in art that is visible to everyone, not only in the churches but also in people's homes - this is Christian and almost equal to the written word. ${ }^{12}$ Here the role of art is clearly educational. However, in addition to this moderate approach, a more critical attitude toward art can also be discerned from Luther's comments. Thus, he states that against his will, he always sees a picture when he imagines Christ. ${ }^{13}$ But can we / or is it good if we have a sensuous picture of Christ? The answer is that, based on such experiences, great importance should be placed on visual censorship because, if words or prayer can evoke pictures in one's heart, the question of what names or words are these pictures associated with becomes very important. ${ }^{14}$ This competition for a place in people's hearts becomes the decisive question when considering the attitude toward pictures. Karlstadt, a reformer who was much more radical than Luther, speaks explicitly about how people must free themselves of all human pictures in order to accept God's picture. ${ }^{15}$ In a sense, Calvin takes a similar position, when he stresses that God is so distant and different from man that no image can convey him and may even be a hindrance. Thus, he arrives at the

10 Eric W. Gritsch and Robert W. Jenson, Lutheranism: The Theological Movement and Its Confessional Writings (Philadelphia: Fortress Press, 1976), 200-201.

11 Thomas I. Bacon, Martin Luther and the Drama (Amsterdam: Rodopi, 1976), 28-29.

12 Sergiusz Michalski, The Reformation and the Visual Arts: The Protestant Image Question in Western and Eastern Europe (London: Routledge, 1993), 27.

13 Martin Luther, Werke. Kritische Gesamtausgabe. Schriften 1525, ed. Joachim Karl Friedrich Knaake, vol. 18 (Weimar: H. Böhlaus, 1908), 83.

14 Arndt Schnepper, Goldene Buchstaben ins Herz schreiben: die Rolle des Memorierens in religiösen Bildungsprozessen (Göttingen: Vandenhoeck \& Ruprecht, 2012), 74-75.

15 Michalski, The Reformation and the Visual Arts, 49. 
conclusion that images and statues must be removed from churches, but he believes that they may exist at home - away from sacral spaces.

Therefore, the church must be very selective about which images to present to the people (and whether to present them at all), because inevitably they will start to be associated with the church's message. From this perspective, greater control and supervision is required in regard to artistic depiction. The result is the unsanctioned depiction of religious subjects in art is condemned and the well-known process of art secularisation gains momentum. A new public space starts to slowly develop in the Protestant countries, which means that a clear line is drawn between the religious and secular, and a secular space develops with very fewer religious images and activities.

During the $17^{\text {th }}$ century, many new movements are added to the existing post-Reformation religious denominations, and it becomes clear that it is unrealistic to hope that common doctrinal ground can be found among the religious differences that developed in the course of the Reformation. The Peace of Westphalia established a situation where the various denominations are allowed to practice their faiths both publicly and privately, as long as no unrest results. The public space can be based on all the common interests and during the $17^{\text {th }}$ and $18^{\text {th }}$ century a tactic develops of increasingly directing possible disruptive activities away from the public sphere, i.e. to the private sphere. ${ }^{16}$

In this situation, it was possible to react in two ways on the religious plane: to draw more sharply boundaries between "us" and "them" in the associations separated from the public space; or to seek common ground between all Christian denominations, or all religions, that could continue to provide the basis for the standards in the public space, including in questions of morality, education, etc.

On the one hand, the enlightened intellectuals of the $18^{\text {th }}$ century found common ground among all religions in the providence of a benevolent and just God and in the immortality of the soul, and on the other hand in universal virtues, such as justice, munificence, etc. The belief in the universality of these principles and virtues relied primarily on the legacy of classical antiquity, which formed the basis for Christian thinking and culture and was a significant part of the education of the day. Thus,

16 Benjamin J. Kaplan, Divided by Faith: Religious Conflict and the Practice of Toleration in Early Modern Europe (Cambridge, MA:Harvard University Press, 2009), 194-195. 
one consequence of separating Christian religion from art was that, at a time when dealing with Christian subjects was still a touchy subject the Protestant space, people often started to speak about issues related to religious searching, salvation and virtue through the concepts and stories of classical antiquity. In Johann Georg Jacobi's Elysium, a prelude with verses, which was published in 1774 , virtuous souls meet on the Elysian Fields after their death and, in the course of the drama, it becomes clear which beliefs, attitudes and actions will ensure the souls a good afterlife and which will cause suffering and remorse. In this way, antiquity provided a seemingly neutral zone, where people with various religious convictions could meet and discuss the questions that were important to them.

In the late $17^{\text {th }}$ and early $18^{\text {th }}$ centuries a movement critical of the church called Pietism, which gets its start from the texts of the very influential Johann Arndt and Philipp Jakob Spener, becomes popular in Germany. The goal of Pietism was to reform people's lives in the same way that the Protestant Reformation had reformed the teachings. And the conversion from external (sensuous, habitual) belief to inner (true, personal) belief was its main aspiration. From the Pietist point of view, being a Christian meant adopting attitudes and lifestyles that were in sharp contrast to the aspirations and habits of the sensuous world. However for Pietists, the condemnation of the world did not mean a rejection of the world, but a religious obligation to make it a more spiritual and better place. Thus, on the one hand, Pietism requires detachment from worldly matters and, on the other, a special care and concern about what is happening in the public space; because the public space is where the Christian love of fellow man is implemented, but also where a true Christian must fight the difficult battle to remain on the narrow path to salvation. As such, the concept of adiaphora is largely repudiated, because nothing is insignificant when it comes to reforming a person's life.

What place does artistic activity have in such a situation? Does it largely coincide with social or religious goals like in the Middle Ages, or does it have some different purpose that is not overlapping with those of society or religion? What benefit does society derive from artistic activity?

In $18^{\text {th }}$-century Germany, such issues were discussed in all the circles of society (ecclesiastic, artistic, education, economic, etc.) thereby 
establishing a basis for aesthetics as a discipline related to art theory. If, in the early $18^{\text {th }}$ century, the German philosophers still dealt with art as part of the technical field or technology, ${ }_{1}^{17}$ by the end of the century, the arts had become independent. Alexander Gottlieb Baumgarten, who introduced the word "aesthetics" into art theory, uses the word to allude to the perception of the senses and as such the arts reflect the world that we live in. In Greco-Roman philosophy, aisthēsis meant anything perceived by the senses (hearing, sight, smell, etc.), but Baumgarten gives it a Neoplatonic emphasis by describing it as a means of expressing the beauty and truth hidden in the world. As such, it is possible to speak of all the arts together (visual, auditory, etc.) without classifying them into subtypes. Also in this article, the word 'art' has been used generally to denote all the images and objects created by man, without giving the word a positive or negative connotation.

However, the general objective of this article is not to deal with the systematic art theories of $18^{\text {th }}$-century Germany - the positions of Wolff, Gottsched, Baumgarten, Mendelssohn, Lessing, or Herder. The article's sphere of interest is the attitude toward art at the practical level. The authors are interested in the following: which arguments were used in the conflicts that developed, and what expectations and assumptions accompanied these arguments. The authors have also sought a clearer understanding of the placement of art on the scale of beneficial-useless-harmful, based on the aims (related to society or religion) that have been stated by the proponents or assumed by default. The question's broader background includes an interest in how the reputation of art is connected to the goals assigned to it and how the corresponding trends compare with the reputation of religion in society.

\section{THE HAMBURG OPERA CONTROVERSY AT THE END OF THE $17^{\mathrm{TH}}$ CENTURY}

The text-centred school theatre, which was organised within the framework of rhetorical education and performed outside of school, i.e. in

17 Christian Freiherr von Wolff, Philosophia rationalis sive logica (etc.) Praetermittitur discursus praeliminaris de philosophia in genere (Francoforti: Office Rengeriana, 1728), 33 (\$71). Possibilis quoque est philosophia artium, etsi hactenus neglecta. Eam Technicam aut Technologiam appellare posses. Cornelia Buschmann, "Ein Begriff für Wissenschaft und Kunst? - Technologie bei Christian Wolff," in "Nützliche Künste": Kultur- und Sozialgeschichte der Technik im 18. Jahrhundert, ed. Ulrich Troitzsch (Münster: Waxmann, 1999), 26. 
Fig. 1. Hamburger Opera Theater on Gänsemarkt. The house was relatively unmarkable half-timbered building with unusually deep stage, sophisticated stagemachinery and room for ca 2000 people. Drawing by Peter Heineken 1726 (Staatsarchiv Hamburg).

the public space, was mostly regarded favourably in the Lutheran context. In the theatrical sense, this poor and thematically limited form of theatre was presented as a positive - educational and intellect-oriented - counterweight to the merry improvisational games that were part of the Shrove Tuesday celebrations, and represented a condemned, but popular, branch of secular theatre. The travelling troupes that appeared in public originally came from the Catholic areas, from Italy and France, and later mainly from England. However, during the $17^{\text {th }}$ century, groups of German actors became increasingly popular and theatrical performances were also organised in many homes. The more demanding dramas, operas and ballets came almost exclusively from Italy and France, and were performed only at court. The first controversy to be examined in this article occurred in connection with the opera expanding 
beyond this narrow circle - with the establishment of an opera house in Hamburg in 1678. ${ }^{18}$

It seems worth mentioning that the first opera performance in Hamburg was of a religious nature and, before the completion of the opera house, was performed in a church. Pastors Anton Reiser (1628-1686) and Johann Winckler (1642-1705) reacted angrily and demanded explicitly that the town council should ban the opera. ${ }^{19}$ In Hamburg different denominations did not compete on the religious landscape, but Pietism did challenge Lutheran orthodoxy inside the church and started drawing new lines of separation between genuine and non-genuine Christians within the same denomination. The Pietists also turned their attention to improving society based on their beliefs. Many of them believed that art - both secular and religious - was something that not only was useless for making the world better, but moreover undermined the ideal, and therefore contradicted both social and religious goals.

Thus three years after the opening of the opera house, Reiser writes his work called Theatromania, oder die Wercke der Finsterniß in denen öffentlichen SchauSpielen von den alten Kirchen-Vätern verdammet. ${ }^{20}$ The book consists almost entirely of references to an awe-inspiring number of extra-Biblical sources, which can be divided into four groups: Latin-speaking church fathers, Greek-speaking church fathers, ecclesiastical councils and finally also pagan (Roman) authors. In the preface written on his own behalf, Reiser justifies his reliance on the authority of the church fathers based on their "apostolic religious fervour" and, based on 1 Cor 4:9, also constructs a Bible-based argument against theatre as such. For Reiser, it was impossible that theatrical art could help the church in its educational work. Theatre was to be condemned for its form alone, ontologically. Religion/the church could not only manage without art, but should do so because true faith is only possible without art.

18 David Yearsley, “The Musical Patriots of the Hamburg Opera: Mattheson, Keiser, and Masaniello Furioso", Patriotism, Cosmopolitanism, and National Culture: Public Culture in Hamburg 17001933 (Amsterdam: Rodopi, 2003), 33-54. Gisela Jaacks, Hamburg zu Lust und Nutz: bürgerliches Musikverständnis zwischen Barock und Aufklärung (1660-1760) (Hamburg: Verein für Hamburgische Geschichte, 1997).

19 Christian Bunners, Geschichte des Pietismus. Edited by Hartmut Lehmann. Vol. 4. (Göttingen: Vandenhoeck \& Ruprecht, 2004), 440.

20 Anton Reiser, Theatromania, oder die Wercke der Finsterniß in denen öffentlichen SchauSpielen von den alten Kirchen-Vätern verdammet (Ratzeburg: Nissen, 1681). 
And the suffering of the apostles was not secret and hidden there, [...] it was if the apostles had to see their suffering and persecution occurring in a theatre and on a public stage and be mocked by everyone. [...] Therefore, he says and writes: we have become a spectacle and are fools; this means that whenever the world has nothing to do, one or more fools should be handy, who must amuse the spectators, thereby we allow ourselves to be mocked by the learned world, and provide them with entertainment. ${ }^{21}$ [...] it is truly inappropriate and actually unchristian to perform a sad Passion with our fellow Christians and to present this in a play in a theatre of anti-Christian persecution. ${ }^{22}$

A stage is a place of abuse and mockery, where we mock those for whom we, as Christians, should feel and demonstrate compassion. Instead of amusing ourselves, we should act to eliminate the troubles of our fellow men. The stage represents anti-Christianity and as such is in the service of evil: "The infernal spirit of death along with its damned angels feels the greatest joy and merriment from the fact that we too have taken up the pen to write verses." ${ }^{\prime 23}$ The goals of religion and art are unambiguously contrary. While religion directs and supports the inner growth of people, art simply entertains people at the expense of others. It hardens their hearts and closes their eyes and ears to the woes of their fellow men and to the voice of God. From a Pietist viewpoint, art distracts people from the correct path and goal. A few decades later, the Pietist-minded Friedrich Wilhelm I, King of Prussia, also describes how comedy can interfere with the self-discipline achieved by diligent work: "if one [after attending a performance] wants to pray, receive communion and hear God's word, the pranks come back to mind again and again."'24 Unlike Reiser, who could only suggest in writing to have an opera ban imposed, the Prussian king had the power to create considerable obstacles for theatre in his realm, keeping in mind his princely and fatherly responsibility alluded to above.

From Reiser's argument, we can conclude that art is not, for example, a didactic tool in the service of an idea, but art has an almost independent nature and goal, not dependent on the way it is used. On the one

\footnotetext{
21 Reiser, Theatromania, 5.

22 Ibid., 12.

23 Ibid, 6.

24 Richard L Gawthrop, Pietism and the Making of Eighteenth-Century Prussia (Cambridge; New York : Cambridge University Press, 1993), 208.
} 
hand, it is apparent that Reiser perceives art as being in opposition to religion, but on the other hand, it turns out that he takes art seriously even when it is in secular context and therefore does not assign it to the field of adiaphora. A similar attitude was already discernable amongst early reformers - when Luther had a moderate attitude toward art and did not consider it to be an important question, then Calvin was suspicious of the concept of adiaphora generally and therefore took any kind of artistic depiction more seriously. This caused a paradoxical situation, when the opponents of art are taking it more seriously and see it as something independent and very influential. When Reiser argues against opera he also uses Roman authors to confirm the universality of his position - not only Christians but all sensible and virtuous people from the pagan world share his assessment. Therefore theatrical arts are harmful to any kind of society.

Reiser's criticism is disputed by at least two well-known people. In the same year that Reiser's book is published, mathematician and philosopher Gottfried Wilhelm Leibniz is asked to comment on Reiser's remarks in correspondence ${ }^{25}$ and he takes a position against the demonization of the stage. Leibniz also states that the theatre does not have any independent goal or nature that can be praised or condemned.

Despite this (abundance of opinions), it is my modest position that such a singing play is nothing more than a very well-thought-out means of very powerfully touching and influencing people, because impressive events, chosen words, artistic rhymes, majestic music, beautiful paintings and artistic movement all come together and by entertaining both the inner and outer senses serve the human senses most excellently. Just like eloquence can be used for both good and bad purposes, so can this rediscovered means of affecting be employed on behalf of a person's lust, desire for revenge, and arrogance, but it can also be employed on behalf of virtue, fidelity, true honour and pristine piety. I believe that these plays in public spaces should not be gotten rid of but used as a strong instrument for governing the common people. It would be appropriate for the superiors and pastors to see to it that this means be used properly; it is true for some comedies that they cause more harm than benefit, such as the so-called Festin de pierre ${ }^{26}$, in which an atheist appears.

25 Gottfried Wilhelm Freiherr von Leibniz, Leibnitz's deutsche Schirften. Vol. 1-2. (Berlin: Veit \& Comp., 1838), 456-457.

26 Reference to Moliere's scandalous play Dom Juan or The Feast with the Statue. 
Therefore, the benefit or harm caused by art to the society depends on the way it is used, and care must be taken to ensure that it stands for "virtue, fidelity and pristine piety" and not for "lust, a desire for revenge or arrogance". Therefore, as a controlled resource with great impact, art belongs in the public space - there is no reason to separate it from religion or society. Instead it should be employed in the service of both. Thus, Leibniz's approval of theatrical activities contradicts Reiser's reasoning - art does not have its own goal or nature.

In 1688, Hinrich Elmenhorst, a theologian, author of church songs and opera libretti who was the pastor of the St. Catherine's Church in Hamburg ${ }^{27}$, provides an answer similar to Leibniz's to his colleague Reiser. Elmenhorst accuses Reiser of a one-sided and unduly self-confident interpretation of the Scriptures and tradition, and confirms that the theatre is part of the field of adiaphora:

The things about which the Scriptures do not provide exact commandments, which are not mandated or forbidden, are defined as adiaphora or indifferent things; therefore they are classified as Christian freedom..$^{28}$

Elmenhorst carefully reviews the accusations of the church fathers and concludes that they were duly justified in that context, but do not apply to the Hamburg opera house because, in this case, the theatre is not part of a church service. In it, tribute is not paid to gods, the sanctity of God is not mocked, sacrifices are not made to idols, Christianity is not ridiculed or Christian teaching violated. It neither teaches people to worship idols nor teaches them disgraceful lechery, depravity, or shameless dances. And it does not teach them to commit strangling or bloodshed. ${ }^{29}$ Thus, absolute opposition to the theatre cannot be supported by the Scriptures or tradition and is rejected. This means that decisions about the theatre must be made based on non-religious criteria. Elmenhorst cites order and unanimity in society as the main bases:

27 Heinrich Elmenhorst, Dramatologia Antiquo-Hodierna: Das Ist: Bericht von Denen Oper-Spielen, darin gewiesen wird, was sie bey den Heyden gewesen, und wie sie des darbey vorgegangenen abgöttischen und lasterhafften Thuns halber von den Patribus und Kirchen-Lehrern verworffen, ferner was die heutige Oper-Spiele seyn, und daß sie nicht zur Unerbarkeit, und sündlicher Augen-Lust, sondern zur geziemenden Ergetzung, und Erbauung im Tugend-Wandel vorgestellet, dannenhero von christlicher Obrigkeit, als Mitteldinge wohl können erlaubt, und von Christen ohne Verletzung des Gewissens geschaut und angehöret werden. Aus Liebe zur Wahrheit geschrieben (Hamburg: Georg Rebenl. Wittwe, 1688).

28 Heinrich Elmenhorst, Dramatologia Antiquo-Hodierna, 3.

29 Ibid., 184. 
However, this [Christian freedom] does not give anyone the right to privately undertake public changes and innovations regarding these matters; this can only be done by the church, and the local superiors must decide [...], also experience has shown that [...] the differences of opinion in church matters, and therefore, also in indifferent things, breeds much unrest for a city. Thus, in such cases, it is more appropriate to recall the [words] of Luther, than to remain true to one's unfounded folly. Luther's words on page 524 are as follows: "Only between God and a person is freedom total and ideal, but between you and your fellow man and you and your superior it is not..."30

Elmenhorst points out that in antiquity the topics that one could calmly discuss at school and at home, but not in presence of wider audience or in the public space, were already identified. Therefore, one must be careful about what is allowed in the public space and what is not, especially keeping in mind the effect on the young and the irrational. As a rule, the latter is the most important factor for deciding what happens in the public space. Elmenhorst explains that during antiquity, plays also had a didactic purpose - to teach the illiterate what they needed to know, and to distinguish between virtue and depravity in an entertaining way. Opera too is not just a delight for the eyes. Therefore, the entire question is who uses the theatre as a tool and for what purposes. Of-course, it is sometimes misused today, as it was in antiquity, but given the influence of Christian superiors on performances at the Hamburg opera house, there was no fear that something would be performed that contradicted Christian faith, morals or customs. Elmenhorst limits himself to the defence of the Hamburg opera and leaves open the question of the conformity of other theatrical activities to the given requirements. ${ }^{31}$

Thus, Elmenhorst clearly differentiates between artistic activity in the sacral sphere (as part of a church service), in learned company and the private sphere, and in the public space. Each sphere has its own standards - theatre has no place in church services, but in a Christian society (under the control of Christian superiors) one need not fear that performances in the public space might somehow be harmful for achieving religious goals. Therefore, one can conclude that in a pagan society, the acceptability of theatre for Christians should be taken under discussion

30 Elmenhorst, Dramatologia Antiquo-Hodierna.

31 Ibid., chapter 1 
again - based on what the theatre teaches to people and who does the teaching. The impact of the theatre on people differs, depending on their age and apparently also their education - e.g. the repertoire that is more complicated in the moral and religious context is not appropriate for the public space.

THE HAMBURG OPERA HOUSE AND GERMAN DRAMATIC ART 50 YEARS LATER

Fifty years after the establishment of the Hamburg opera house (1728), Johann Mattheson, a composer, music critic, diplomat, pamphleteer, translator, political commentator and Hamburg's respected public figure, writes a book called Der Musicalische Patriot in celebration of the theatre's jubilee. In it, he discusses the history and foreseeable future of the theatre..$^{32}$ Mattheson's emphasis is on music - by defending art, he is primarily defending music, theatrical and otherwise. If the Hamburg opera controversy was caused by a very serious (but negative) attitude toward art, Mattheson seems to feel keenly that what is lacking now is a serious attitude. ${ }^{33} \mathrm{He}$ exclaims that art (music) is earning undeservedly little respect in society! Mattheson points out everything for which art (music) is beneficial, downright necessary and even irreplaceable. Unlike the two pastors active in the later $17^{\text {th }}$ century (and more similarly to the cited philosopher) Mattheson considers art (music) to be essential for Christian religious life. He speaks about the simultaneous trend in art (music) and religion (Christianity). Not only sacral, but also secular, music glorifies God, and both are capable of promoting common values and improving people. ${ }^{34}$ One does so in church and the other - if correctly organised - amidst the bourgeoisie, by providing moral guidance and by pointing out the uncertainty of human greatness. ${ }^{35}$

\footnotetext{
32 Johann Mattheson, Der musicalische Patriot: welcher seine gründliche Betrachtungen über Geistund Weltl. Harmonien samt dem was durchgehends davon abhänget in angenehmer Abwechselung zu solchem Ende mittheilet das Gottes Ehre das gemeine Beste und eines jeden Lesers besondere Erbauung dadurch befördert Verde. (Leipzig: Zentralantiquariat der Dt. Demokrat. Republik, 1975 [1728]).

33 David Yearsley, "The Musical Patriots of the Hamburg Opera: Mattheson, Keiser, and Masaniello Furioso", Patriotism, Cosmopolitanism, and National Culture: Public Culture in Hamburg 1700-1933 (Amsterdam; New York: Rodopi, 2003) 33-54.

34 Mattheson, Der musicalische Patriot, title page.

35 Mattheson, Der musicalische Patriot, 176.
} 
Mattheson declares that music is the basis for a society's ethical health! If Leibniz spoke of the opera house as a good means for governing the common people, Mattheson describes its moral task as guiding the upper class. At the opera, the nobility and rulers are encouraged to think about the general wellbeing and to implement enlightened political programmes in their domains. Music, and especially dramatised music (opera), is the soul of society, which has an irreplaceable political function. ${ }^{36}$ Thus, we are no longer talking only about the visual teaching of the illiterate but also influencing the social elite and providing proper inspiration.

Yet, the benefits of musical activity are not limited to influencing people spiritually and morally - opera specifically, and music more broadly, also has an economic role - by hosting rich opera lovers, the city gains in the fields of learning, art and commerce.

Learning, art and handicrafts blossom along with the opera. Therefore a city gains as much from a good opera house as from a good bank... the latter takes care of general security, and the former, of education and stimulation. ${ }^{37}$

From Mattheson's arguments, we can conclude that not only are religion and correctly organised art dealing with the same thing, but that religion absolutely needs the support of art. However, on the social plane, art's scope exceeds that of the church and therefore art (music both dramatised and not) must stand at the centre of the public space and guide and inspire people. It is society that badly needs art in the moral, political and economic sense. Mattheson sees art as something more than a respectable means of serving the goals of religion and society, but at the same time, art does not seem to be working in the name of any distinct goal. Rather, we get the impression that we are dealing with a concept that is comparable to the medieval times, but this time art seems to have qualities that connect it even more directly with the sphere of ideas, eternity and God. Therefore art does not acquire the respect it deserves due to its singular goal, but because it shares the same ultimate goal with society and religion.

36 Mattheson, Der musicalische Patriot, 28.

37 Ibid. 
Fig. 2. Travelling troupe performing in the middle of 18th century Germany. Oil painting by Johann Christian Vollert.

Until now, only opera has been under discussion - a genre requiring a great expense, conforming only to the taste of the upper class and therefore aspiring to a higher-order of social respect. The dramatic art of the travelling theatrical troupes generally depended on the taste and approval of the common people and was therefore usually condemned by intellectuals who questioned what it had to offer the public and what the public could learn from it. In 1729, Johann Christoph Gottsched, who was a leading figure on the German literary and theatrical landscape in the second quarter of the $18^{\text {th }}$ century, gave a speech to an academic public in defence of the art of theatre. The need for this was caused by those who attacked the theatre, who the professor of poetry speaks of generally as people labouring under deeply seeded prejudices, unwilling to listen to even the most convincing and reasoned conclusions. ${ }^{38} \mathrm{He}$ differentiates these under-enlightened people as follows: the first group condemns theatre without really knowing it; the second group draws its conclusions about the entire genre based on a few abuses and is willing

38 Johann Christoph Gottsched, “Akademische Rede. Die Schauspiele, und besonders die Tragödien sind aus einer wohlbestellten Republik nicht zu verbannen“, Ausgewählte Werke. Gesammelte Reden, ed. P. M. Mitchell, vol. 9/2 (Berlin: Walter de Gruyter, 1976), 492-500; 564-575. 
to throw the baby out with the bathwater; the third group brings exceptional piety as the reason that forces it to scorn the theatre purely on account of conscience. ${ }^{39}$ Gottsched defends the theatre and carefully separates the wheat from the tares - there is theatre that is beneficial when it comes to religious and social goals, and there is theatre that is harmful in every sense. As an example of the latter, he speaks about the "theatrical miscarriage" that is presented under the grand name Hauptund Staatsaktionen:

Far from defending and praising this contemptible form of theatrical art, I must abhor and reject it. Because these plays are not the imitations of nature and because they diverge almost totally from probability. They have not been organised with the goal of educating the viewers. They do not arouse any great passions, not to mention trying to put these passions into appropriate frameworks. They are not capable of arousing noble feelings or encouraging the viewers to high-mindedly forgetting misfortunate; instead, they promote cowardice and fear based on the examples of weak and despicable characters. ${ }^{40}$

The plays were the pompous and overstated dramatisations of the murderous deeds of rulers of the distant past, which were alternated with comical interludes. Gottsched's requirements for well-organised theatre that deserves respect are based on a classicist concept, which, among other things, means that art should not mislead the audience (as these performances did) but rather direct it to the truth (as classical tragedy did). Neither the $18^{\text {th }}$-century enlighteners nor the Pietists had any doubt that people must develop and improve - the differences appeared in the details and goals, and their realisation. In any case, it was clear that any poorly produced theatre with dubious morality was only a hindrance, i.e. harmful, to this path of development. However, Gottsched wants to say that it would be just as harmful to reject the entire art form because of these miscarriages - and this is precisely in the context of moral growth. Gottsched argues that appeals to reason, i.e. listening to the persuasive arguments presented in the Scriptures and in sermons, are not sufficient for most people: "Most people are too sensuously accustomed to accepting any evidence that is comprised only of rational connection, if

39 Gottsched, "Akademische Rede. Die Schauspiele”, 493.

40 Gottsched, "Akademische Rede. Die Schauspiele”, 495. 


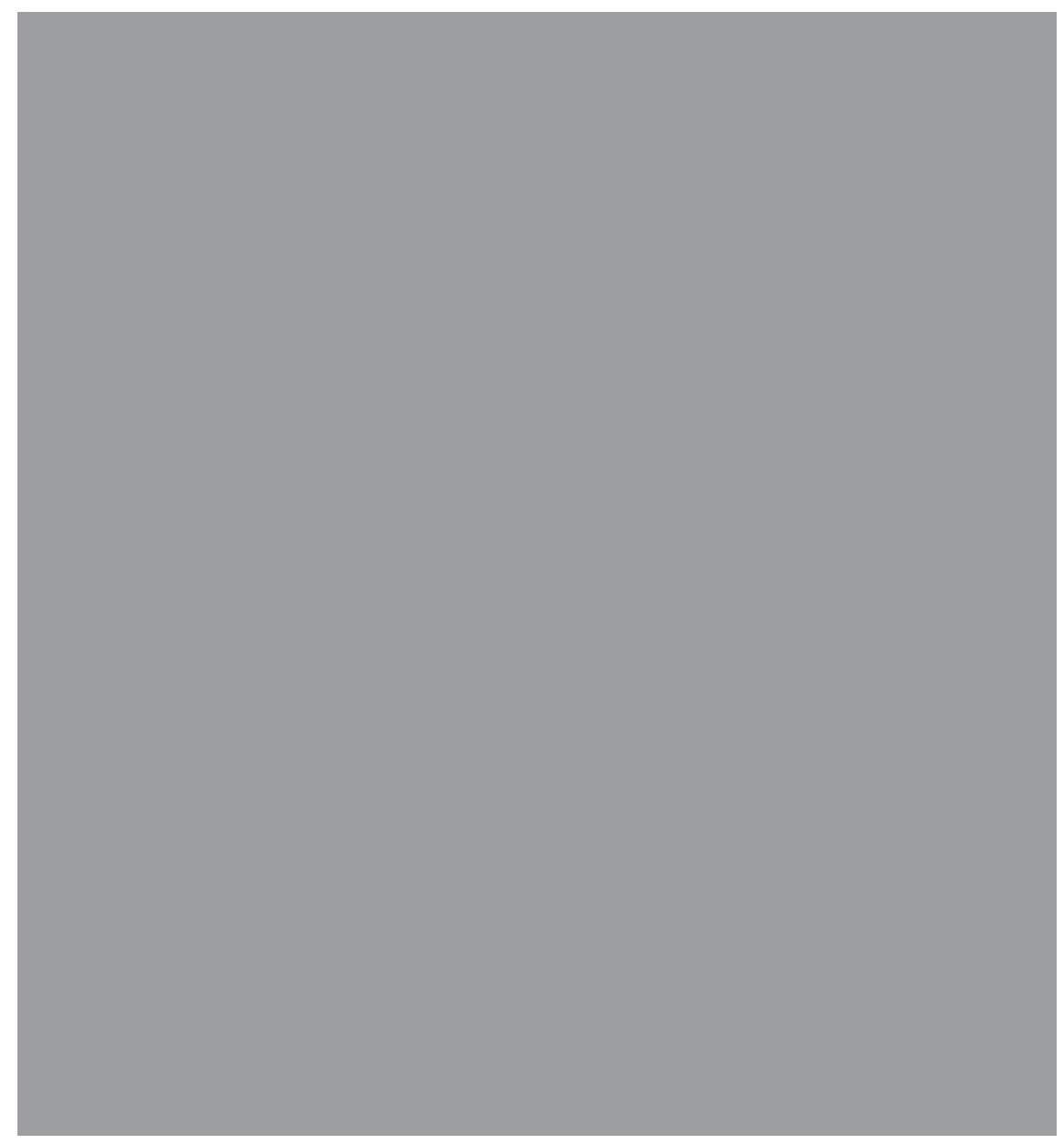

Fig. 3. Theater poster in 1743 advertizing a Haupt-Aktion. It was a popular genre with pompous and overstated dramatisations of the murderous deeds of ancient rulers, which were alternated with comical interludes. For the publicum also Bratwurst and Sauerkraut is promised.

their desires oppose it." ${ }^{\prime \prime 1}$ In order to grow morally, people need to emotionally experience the truths that are accepted rationally, with the help of the relevant examples, and the theatre provides the proper means to do so. However, in order for the theatre to perform this noble assignment, something radical had to be undertaken in regard to the existing drama. According to Gottsched, theatre in a well-governed society that

41 Ibid., 495. 
serves the common good and must have the corresponding content, that is, high-quality texts similar to antique and French masterpieces.

Gottsched proceeded from the conviction that proper theatre will perform the assignment of gradually elevating the public's tastes and reasoning, morals and habits, even against its own will. He describes a person's development as a gradual process, in which experiences can be utilised without the person consciously detecting a lesson:

I hear another reproach that is justified by experience - there is no evidence that these plays have made people virtuous. This reproach does not prove anything. After all, even sermons could not have a soul-exalting effect, if one required that manifest results be immediately achieved in all the listeners. How many misers have become generous, how many drunks temperate, how many adulterers chaste, how many heartless people compassionate and indulgent after hearing a sermon about their vice? [...] Improving the human heart is not a job that can be completed in an hour's time. A thousand preparations, a thousand situations, many realisations, convictions, experiences, examples and reassurances are needed before a sinner gives up his ways. It is enough if one seed after another is thrown into a heart, and then starts to germinate in time and finally bears fruit.

In the cultural space of $18^{\text {th }}$-century Germany, many educated people proceeded from an assumption according to which the core and main message of all the world's religions is the same, and that this universal truth is revealed to people's perceptive ability through natural means (reason, heart, nature). If the explicit religion is of a local character, then the most significant universal truth in keeping with it applies to everyone and, as such, is the normative basis and moral yardstick for all societies. Gottsched is convinced that truly good theatre - i.e. classical tragedy - is never at variance with religion's fundamental principles and universal virtues:

[...] And how could he [Marcus Aurelius] have complained about this, if religion itself, at least the natural one, were unharmed at all times on the theatrical stage? Almost all tragic poets are devoted to Stoic sects or similar teachings about God, and set what these learned people taught in their schools as a requirement for people and repeatedly reminded them of it. Divine providence, God's fairness and goodness, the immortality of the soul, glorification of virtue 
and dishonouring of sins are always predominant in tragedies. Innocence is always presented as a victory and wickedness as a curse. And even if the former is sometimes shown to be ill-fated and the latter fortunate, the actual beauty and ugliness of each becomes apparent and it is unlikely that anyone in the audience would not prefer being unhappy with virtue than happy with sin. The theatre places these healthy concepts in people's hearts even if they had only expected to be amused. They search for the enchanting and find the most nourishing food that is hidden inside." 42

Philipp Balthasar Schütz, an author with Pietist leanings, (under the pseudonym Ludwig Ernst von Faramond) had argued, that all arguments that appeal to the moral benefits of theatre are unfounded, because people do not storm to the theatre to hear Christian morality being preached, instead of smutty love stories. Therefore, it is clear that the audiences at the theatre only want to spend time as pleasantly as possible and not be subjected to religiously exalted or moral teachings. ${ }^{43}$ Schütz includes an assumption typical of Pietism in his argument, i.e. there are no neutral actions - if the reason for going to the theatre is not to receive religious exaltation or moral teaching, i.e. not something that serves a religious purpose, then it therefore contradicts religious purpose. Gottsched surely found the idea of "just being amused" offensive, but for him the motivation of the viewer seems less important than the motivation of the presenter (i.e. the dramatic text and its presentation), which determines the morally favourable or unfavourable consequences for the viewer. However, from a Pietist standpoint, the person's own conscious orientation toward either the eternal or the transitory is most important and "spending time as pleasantly as possible" does not help to prepare for a conversion experience or to stay on the right path after conversion. Apparently, Gottsched is referring to this Pietist belief when he includes "exceptional piety" among the reasons for attacking the art of theatre.

It seems that for Gottsched (theatrical) art is similarly an indispensible tool for assisting in moral growth, as (theatrical) music is for Mattheson, which if properly executed can accomplish things that sermons and the written word alone cannot. It could even be said that both men defend the central role of (theatrical) art as the transmitter and endorser of

42 Gottsched, "Akademische Rede. Die Schauspiele", 498-500.

43 Johann Georg Walch, Historische und theologische Einleitung in die Religions-Streitigkeiten außer der Evangelisch-Lutherischen Kirche, vol. 5.2 (Stuttgart-Bad Cannstadt: Frommann, 1985), 863. 
generally established teachings (although no longer directly connected to a specific church). In this regard, both men assume that harmony can be achieved between religion, arts and the interests of society.

\section{ON RELIGIOUS SUBJECTS IN ART AND THE DRAMATIC ART IN THE MID-18 ${ }^{\text {TH }}$ CENTURY}

As stated above, the reputation of drama in the $17^{\text {th }}$ century was generally negative even in the Lutheran context, and after awhile, the school theatre tradition that was viewed positively by Luther started to die out. In 1762, Johann Gotthelf Lindner, the rector of the Riga Cathedral School, wrote a series of school dramas along with a foreword defending and justifying this theatrical form. ${ }^{44} \mathrm{He}$ dedicated part of his text to a discussion on the religious preconceptions that people may harbour against the theatre, which have resulted in school dramas being driven out of most Protestant schools. Lindner does not seem to allude directly to Pietism, but rather to the antithesis of Protestantism and Catholicism. He considers the basis of the preconceptions to be, above all, the excessive fear of anything Catholic (dramatic activities in Jesuit schools) or things that could be perceived by the more diffident as paganism ${ }^{45}$ (in Protestant rhetoric, the practices of Catholicism were sometimes deemed as "pagan"). Lindner relies on a series of earlier theologians/educators to reassure the readers that Protestantism definitely poses no obstacle to theatre or school drama. Overturning the idea that the dramatic arts and Christianity are at odds, he even talks about dealing with Christian subjects by declaring that "I am not one of those who condemn Klopstock for having made the Messiah the hero of his epic poem. ${ }^{\prime 46}$ Here Linder is referring to Friedrich Gottlieb Klopstock's (1724-1803) voluminous poem Der Messias, which is also considered a turning point that caused the educated classes to switch from explicitly religious texts to belles-lettres for their spiritual guidance. ${ }^{47}$ Alongside this, the approach to Christian

\footnotetext{
44 Johann Gotthelf Lindner, Beitrag zu Schulhandlungen (Königsberg: Woltersdorff, 1762).

45 Ibid., 16.

46 Ibid., 32.

47 Wulf Koepke, "In Search of a New Religiosity: Herder and Lenz", Space to Act: The Theater of J.M.R. Lenz, ed. by Alan C. Leidner and Helga S. Madland (Columbia, SC: Camden House, 1993), 121-131.
} 
subjects and Christianity in belles-lettres and the dramatic arts again became a topic of discussion - on the one hand, there was the desire to (freely) deal with these subjects, and on the other, a more or less nervous attempt to keep them under control (e.g. the ban on performing Lessing's Nathan der Weise with its message about religious tolerance). By dealing with this question, Rector Lindner reveals the misgivings related to the issue, but he confidently confirms that if religious materials are used with total seriousness, the proper spirit and strict decency, it is not only harmless to enjoy dramas based on Biblical subjects, but also provides a means of arousing religious emotions in the very best sense. ${ }^{48}$ From this declaration, we can conclude that the reputation of drama in society had improved enough that the Protestants who considered theatrical art to be neutral from a religious aspect could seriously weigh using drama "for arousing religious emotions", i.e. in the direct service of religious goals.

\section{COMPARISON OF IDEALS AND REALITY IN THE SECOND HALF OF THE $18^{\text {TH }}$ CENTURY}

Gottsched's ideal of a good theatrical play that essentially presents a grain of morality found criticism already during Gottsched's own lifetime. Throughout the $18^{\text {th }}$ century, various theoreticians tried to detach art from the role of moral educator often assigned to it. But even Gotthold Ephraim Lessing, who is considered to the first German playwright, thought that the theatre's primary assignment was educational - the goal of tragedy was to generally cultivate compassion in people through affects. Lessing felt that compassion was the precondition and impetus for moral behaviour:

A more compassionate person is a better person; of all the social virtues, of all the ways of being high-minded, this is the most beautiful. Thus, what makes us more compassionate, makes us better and more virtuous, and tragedy what does the former does also the latter - or to put it another way, does the former do achieve the latter. (Letter to Nicolai, Nov 1756; s 163) p. 171.

Lindner, Beitrag zu Schulhandlungen, 33. 
It (i.e. tragedy) must expand our capacity for compassion. It must not simply teach us to feel compassionate toward one or another unfortunate person, but it must make us sensitive enough that every unfortunate person at any time and in any shape must be of concern to us. (Letter to Nicolai, Nov 1756, s 163.) p.171.

A similar attitude is expressed by Lessing's colleague, the poet and journalist Matthias Claudius, in a fictional conversation in the 1769 issue of the periodical Hamburgischen-Adreß-Comtoir-Nachrichten: a naïve young man, after seeing Lessing's play Minna von Barnhelm" says, "Yes, I truly believe, if you see such people often, you could finally become righteous and noble along with them." ${ }^{\prime 49}$ Based thereon, theatre can only be good - i.e. develop a person morally and spiritually and thereby be beneficial to society - only if it inspires the audience with virtuous protagonists, who always survive various tribulations and meetings with honour. For the same reasons, Lindner, the Riga school director introduced above, feels that such characters are almost the only ones appropriate to be personified by students. Lindner says, "The characters that students depict for presentation must be virtuous, so as their hearts could learn what is noble and beautiful." ${ }^{50}$ Thus, it seems that most of the arguments in the $18^{\text {th }}$ century that stress the beneficial nature of theatre were based on the positive influence of good characters and educational tribulations.

During the latter part of the century the art of theatre had developed to the point that one can already speak of a certain social pressure to visit the theatre and efforts were being made to establish publicly financed national theatres. Now both the supporters and the opponents started to pay more attention to the actual realisation of the goals they had hoped for. Johann Melchior Goeze, a conservative pastor from Hamburg, thoroughly deals with this in his text Theologische Untersuchung Der Sittlichkeit Der Heutigen Deutschen Schaubühne, which is written in 1770 and based on specific cases. ${ }^{51}$ Goeze declaratively addresses only his fellow Christians

49 Gotthold Ephraim Lessing, Minna von Barnhelm oder das Soldatenglück: ein Lustspiel in fünf Aufzügen verfertiget im Jahre 1763 (Stuttgart: Philipp Reclam Jun., 1992), 106.

50 Lindner, Beitrag zu Schulhandlungen, 25.

51 Johann Melchior Goeze, Theologische Untersuchung Der Sittlichkeit Der Heutigen Deutschen Schaubühne, Überhaupt: Wie Auch Der Fragen: Ob Ein Geistlicher, Insonderheit Ein Wirklich Im Predigt-Amte Stehender Mann, Ohne Ein Schweres Aergernis Zu Geben, Die Schaubühne Besuchen, Selbst Comödien Schreiben, Aufführen Und Drucken Laßen, Und Die Schaubühne so Wie Sie Itzo Ist, Vertheidigen ... Könne? (Hamburg: Brandt, 1770). 
and his writing contrasts Christian virtue and the love of fellow man with the pagan world that derides and despises these qualities. Goeze arrived at the conclusion that the church fathers would not retreat from their harsh condemnation of the art of theatre, even at the present time. This in itself adds nothing new to the discussion, but Goeze's further arguments allow us to shed light on an apparently more serious discrepancy between expectations and reality. Goeze proceeds from an assumption with what all the supporters of the theatre supposedly agree on, that before 1728, the theatrical stage was a "school for nonsense, depravity and all sorts of obscenity". ${ }^{52}$ Goeze stresses however, that his analysis is based on the contemporary theatre:

Both sides [the defenders and opponents] are tilting at windmills. Those who damn plays and base this on how the theatre was 30 or more years ago, discredit themselves and provide their opponents with the opportunity to ridicule their condemnations. Just as this means of attack is insufficient for rocking or destroying the theatrical stage today, so too, the reasons presented by the friends of theatre for defending it are insufficient against the attacks of the opposite side. The former are fighting against a theatre that no longer exists, and therefore can do no damage. The latter are defending a theatre that not only does not exist but which can actually never exist. Therefore the issue should be presented as follows: is today's theatre, when viewed as a whole, a building that has fundamentally been built according to the best standards, or it is an old, dressed-up house decorated with wallpaper and paint, which is still fundamentally unfit? [...] Can it truly be compared to a virtuous person who tries to act correctly in all situations for the right reasons; or is it similar to a hypocrite that seems to be virtuous in words and actions, but does not hesitate to trample on the precepts of truth and virtue, if it is to his benefit and his desires demand it? ?53 $^{33}$

Goeze directs our attention to the fact that the defenders of the moral benefit of the theatre rest their arguments on a handful of serious dramatic texts, but these do not comprise the majority of the performed repertoire. And even when one of these high-minded dramas is on

52 Presumably, Goeze is referring to Gottsched's speech, which has already been cited, in which drama that has been subordinated to the corresponding reform is described as a "school of patience and wisdom". Gottsched, Akademische Rede. Die Schauspiele, 494.

53 Goeze, Theologische Untersuchung, 11-12. 
Fig. 4. Lessing's play Miss Sara Sampson, which was first produced in 1755, is said to be the earliest Bürgerliches Trauerspiel in Germany. This new genre was in Germany especially successful and highly esteemed. Typically for that period a comical pantomimic balley (in this case "The scissors-grinder") followed the tragedy. the programme, a humorous harlequinade or pantomime is presented thereafter, which negates all the previous educational work. Goeze's main argument is that, despite the aspirations and efforts of some people to see contemporary theatre as cultivating propriety and virtue, theatre actually still and always remains a (sinful) nest of pleasure, the impact of which is totally opposite to what is claimed. He writes:

If we demand proof of the perfect innocence, purity and great usefulness of present day theatre, then texts by Schlegel, Gellert, Lessing, Cronegk and Weiss are provided as proof. Although there is something to be ashamed of in comedies, the more fervently reference is made to tragedies and that is all the evidence they have to present. [...] I confess that these plays may generally be trustworthy and useful. But can we make an assessment regarding today's theatrical activities and organisation based thereon? Are only, or primarily, these pieces presented? Should we not be worried about the amusing spectacles that follow, and that the pantomimes that always come at the end of the plays not destroying the limited and weak impressions that have supposedly been generated in the viewer's soul? Only today, I saw a posted comedy bill: first it indicated the main play [...]; this was followed by a pantomime: Doctor Faustus. [...] and the pantomime "Victory of the Harlequin [...] How both these pantomimes help to exalt the souls of the citizens, open their hearts and improve their habits, I cannot see. ${ }^{54}$ 
Fig. 5. A picture of a stage of a comedy play from 1750 Breslau. Drawing by J. Wagner.

According the Calvinist leanings of Goeze, depraved human nature is always innately inclined toward evil, and this is why the merry spectacles can so easily nullify the impact of the moral plays. ${ }^{55}$ Thus, it could be said that if Gottsched thought that the people who came just to enjoy themselves can also get useful instruction from good theatre, then Goeze believes that those who have come seeking virtue and propriety will only get disgraceful and harmful fun even from a good theatre.

Goeze's position is extreme, but the difference between the ideals and the reality was also noticed by the promoters and defenders of the theatre. Furthermore, this was broadly a subject of pointed discussions; an example of this is the bitter fight about the establishment of the theatre in Geneva in the middle of the $18^{\text {th }}$ century. Jean-Jacques Rousseau, whose works undoubtedly had a great influence on German intellectuals, fiercely opposed the theatre as a totally harmful art form. The arguments of the formerly fervent theatre lover were based on the contradictions between the supposed emotional purification and development of compassion,

55 In his foreword, Goeze promises to send his text to the theological faculties of some Lutheran and Reformed universities; there is a discussion about the conformity of the theatre to the inclinations of the human heart: Goeze, Theologische Untersuchung, 16. 
and the actual (totally negative) effect. ${ }^{56}$ Rousseau proceeded from the assumption that civilisation distorts the natural development of man and the role of theatre is to direct people to seem rather than actually be like something.

Also Lessing in Germany - who wanted to see the theatrical stage as a place for arousing compassion and becoming accustomed to compassion, which is a precondition for morality ${ }^{57}$ - noticed that gradually improving the public is a very slow process. His participation in the attempt to establish a national theatre in Hamburg made Lessing see that set ways of thinking and behaving were very difficult to change, especially if one hopes to encourage people to think for themselves, instead of teaching them from above. It turned out that the disappointed public just did not attend the theatre anymore, instead of demonstrating its activism by thinking along with the theatre, criticising it and improving it. Lessing never clearly backed down from his previous position regarding the educational goals of the theatre, but after the failure of the Hamburg national theatre he never spoke of it again. ${ }^{58}$

Johann Wolfgang Goethe's novel, Wilhelm Meisters Lehrjahre (Wilhelm Meister's Apprenticeship), which he started writing in 1770 but which was not published until 1795, also describes the collapse of high ideals when they meet up with reality. Wilhelm, who had just gone out in the world on his own, had extremely serious views about working in the theatre and about the theatre public. For example, he says the following when discussing some possible changes in Shakespeare's Hamlet:

"Whoever pays the cash," said Serlo, "may require the ware according to his liking." "Doubtless, in some degree," replied our friend; "but a great public should be reverenced, not used as children are, when pedlars wish to hook the money from them. By presenting excellence to the people, you should gradually excite in them a taste and feeling for the excellent; and they will pay their money with double satisfaction, when reason itself has nothing to object against this outlay. The public you may flatter, as you do a well-beloved

56 Jean-Jacques Rousseau, Johann Gottfried Herder, On the Origin of Language: Jean-Jacques Rousseau, Essay on the origin of languages; Johann Gottfried Herder, Essay on the origin of language, trans. John H Moran and Alexander Gode (New York: F. Ungar Pub. Co., 1967), 8; David Wiles, Theatre and Citizenship: The History of a Practice (Cambridge University Press, 2011), 123

57 Wilfried Barner, Lessing: Epoche, Werk, Wirkung (C.H.Beck, 1998), 197.

58 Barner, Lessing, 198-200. 
child, to better, to enlighten it; not as you do a pampered child of quality, to perpetuate the error you profit from." ${ }^{\prime 59}$

However, after thorough preparations and a brilliant performance of Hamlet, Wilhelm comes in contact with the members of the audience who were generous with their ovations at the premiere:

Wilhelm often mingled with the audience, to ascertain their feelings; but he seldom heard a criticism of the kind he wished; more frequently the observations which he listened to distressed or angered him. Thus, for instance, shortly after Hamlet had been acted for the first time, a youth was telling, with considerable animation, how happy he had been that evening in the play-house. Wilhelm hearkened; and was scandalised to learn that his neighbour had, on that occasion, in contempt of those behind him, kept his hat on, stubbornly refusing to remove it till the piece was done; to which heroic transaction he still looked back with great contentment. ${ }^{60}$

Thus, even the greatest enthusiasts of the theatre are forced to confess that the influence of the theatre on people's development is not as strong and positive as hoped. However, this does not necessarily mean that all the relevant endeavours should be abandoned. Even assuming that the goal of a work of art is purely aesthetic - to be pleasant, beautiful and entertaining - the question remains, to what extent is it possible to totally separate the moral dimension. One possible solution is to make the elevating influence of the work of art dependent on the receptiveness of the recipient - some people have a greater "formative capacity" than others. Some time later, the following is said to Wilhelm in the Lehrjahre: "The public is large; true judgment, true feeling, are not quite so rare as one believes, ${ }^{\prime \prime 1}$ but the belief that the theatre can be an educational tool for the masses seems to have been weakened. Johann Georg Sulzer's Allgemeine Theorie der schönen Künste, which was published between 1771 and 1774 and was the first German-language encyclopaedia

59 J.W. von Goethe, Wilhelm Meister's Apprenticeship. The Harvard Classics Shelf of Fiction (New York: Collier \& Son, 1917), Book V, Chapter IX, 9-10.

60 Goethe, Wilhelm Meister's Apprenticeship, Book V, Chapter XV, 6.

61 Ibid., Book VII, Chapter VIII, 65. 
to systematically deal with all the $\operatorname{arts}^{62}{ }^{6 x}$ expesses one aspect of the educational role of theatre:

However, (the play) having an inner perfection and correct ideas is more important. The general content and individual parts of a play must not only be interesting and entertain people of good taste with uninterruptedly lively affairs of the spirit and heart, but finally leave an impression that has the best effect on the soul... The fear that the poet arouses in us but serves the goal of avoiding evil; laughing must keep us from being a laughing stock; every human emotion must make us active; but it all must proceed to the goal of setting our soul into a beautiful harmony of emotions so that it becomes sensitive to good and evil in suitable measure. ${ }^{63}$

On the other hand, references to the limited realisation of these goals or a dependency on certain people in the audience can be noticed:

It is not unheard of for people to experience noticeable changes in their way of thinking as the result of small words they have taken to heart. Undoubtedly it is good, when people hear important truths in the places where they experience the strongest emotions. Even if it [the wisdom under discussion] does not affect everyone or affects them less strongly, there are still cases when it has a great impact. In this way, a drama becomes the most beneficial work of poetry and a theatrical play becomes a high-minded and useful activity for the thoughtful and sensitive viewer. ${ }^{64}$

Here the opinion is clearly expressed that the art of theatre deeply affects only some people, but even for the sake of those few theatre goers it is a beneficial and commendable activity and certainly not harmful to less sensitive souls. This concept accepts the limits on the usefulness of theatre and implies that theatre is predominantly perceived as entertainment.

This raises the question whether something that is (mostly) fun and organised in the public space and publicly financed is really useful or

62 Johann Georg Sulzer et al., Allgemeine Theorie der schönen Künste in einzeln: nach alphabetischer Ordnung der Kunstwörter auf einander folgenden, Artikeln abgehandelt (Frankfurt, 1798).

63 Sulzer, Allgemeine Theorie der schönen Künste, 768j.

64 Ibid., 796-770. 
beneficial from the viewpoint of a general population and a well-governed city.

\section{ECONOMIC AND TIME MANAGEMENT ARGUMENTS}

Already in the late $17^{\text {th }}$ century (1685), in the dispute about the Hamburg opera house, Gerhard Schott, the theatre's director and one of its main financiers, uses the promotion of economic and social wellbeing as one of the defensive arguments for theatre ${ }^{65}$ Firstly he confirms that the theatre is unconditionally subordinated to the established standards that apply in the public space and the necessary censorship by the city authorities and the church. But he tries also to show how the opera house will be beneficial to the city in every way, regardless of the question of morality under discussion. He explains that the impact of the opera on the general citizenry will be small in the moral context, because most of the visitors are aristocrats or foreigners. Yet, there will be a considerable positive impact on the economic side, because a high-quality opera house brings fame and income to a city - donations are made to the fund for the poor and thus also students can study longer. Schott does not try to present the opera house as being beneficial in a moral context, but argues that it benefits the city economically. Therefore, Schott is essentially saying that even if art is, in some sense, questionable, this bad influence can be limited and still be indirectly implemented for society's wellbeing.

Almost a century later, the citizens of Hamburg themselves are going to the theatre and are so enthused by this art form that, in 1775, the funeral of the young actress Charlotte Ackermann becomes an occasion for city-wide mourning and a large amount of money is collected in a short time to erect a memorial to the young woman. ${ }^{66}$ In this connection, the theatre lover and journalist Albrecht Wittenberg feels the need to bring the townspeople back to earth:

If we look at this cold-bloodedly, Charlotte Ackermann was nothing more than an actress, who had not even reached the top of her art; she was nothing more

65 Jaacks, Hamburg zu Lust und Nutz, 87-88. Vt viide 18!

66 Ruth B. Emde, Schauspielerinnen im Europa des 18. Jahrhunderts: ihr Leben, ihre Schriften und ihr Publikum (Amsterdam-Atlanta: Rodopi, 1997). 
than someone who knew how to let us have a pleasant time for a few hours; who could contribute something [...] to the promotion of our sensuous delight.

After all, the theatre is still only a place for pleasantly passing the time, which we should not undeservedly raise to a higher position and thereby waste too much money. In the same way, Johann Friedrich Teller, an evangelist cleric from Leipzig, separates art from its educational goals in his text Von der wahren Güte der Schauspiele für beyde Partheyen, which was published in $1776 .{ }^{67} \mathrm{He}$ says to the congregation that the theatre is allowed to them as a useless merriment. This means that as long as no one tries to learn from this merriment, theatre can be calmly considered a useless, but still permissible way to pass the time. Although, it is clear that Teller's functional differentiation cannot be considered to be any kind of general consensus, ${ }^{68}$ the opportunity to deal with the theatre as a purely entertaining undertaking seems to significantly simplify the situation for many. In the next two examples, which are both from the Baltic countries, the usefulness and harmfulness of the art of theatre is discussed primarily from the aspect of the sensible utilisation of time, and no longer from the viewpoint of its educational or moral benefit.

Karl Philipp Michael Snell (1753-1806), an educator, cleric and writer, who had also tried his hand at playwriting, compiled a text in Riga that was structured like a play, in which the classical Greek philosophers Plato and Epicurus weigh the arguments for and against theatrical activity in such a well-governed city like Riga was in $1785 .{ }^{69}$ The ghosts familiarise themselves with the city of Riga and the recently built city theatre and finally both deliver their verdicts regarding the theatre - one is negative, the other positive. Snell writes that Plato's arguments against theatre are not directed at the art of theatre as such - every sensible person knows that a naturally pleasant and useful theatre is self-evidently part of an enlightened society. Snell's Plato asks instead, is the theatrical activity

67 Johann Friedrich Teller, Von der wahren Güte der Schauspiele für beyde Partheyen (Leipzig: Schneidern, 1776).

68 E.g. Teller immediately gets an answer from the drama critic Friedrich Theophil Thilo (17491825): „Unmassgebliches Gutachten über die von Johann Friedrich Teller herausgegebenen Abhandlung von der wahren Güte der Schauspiele für beyde Parthien" Johann Christoph Adelung, Allgemeines Verzeichniß neuer Bücher: Mit kurzen Anmerkungen nebst e. Gelehrten Anzeiger, Volumes 2-3, (Leipzig: Crusius, 1778).

69 Karl Philipp Michael Snell, Patriotische Unterhaltungen (Riga: G.F Keil, 1785). 
- as nice and useful as the Riga city theatre with its proper repertoire is - economical in the given situation as a whole?

If I want to make the right decision about something, I must view it from various standpoints. The place and time often can change something into quite the opposite and make something that is laudable on its own into something undesirable. If, for instance, I have a yard that is 3,000 square fathoms, I can design 500 of it into a pleasance, without causing the property any harm. But if the entire yard is only 500 square fathoms, it would clearly be stupidity to include as many lanes, garden houses and beautiful glades there as in the yard where 5/6 could still be used for economic purposes. [...] Now imagine a play as such a pleasance, which the owner has established. I am afraid that upon closer examination, its ratios would turn out to be ones that are in opposition to the inner strength of the state, in many places too large and outsized and therefore must be trimmed back to a more suitable dimension, or if this is not possible, discarded. [...] The entire state must be viewed like a household, like a family in whose hands a certain sum of money circulates, for which they can jointly acquire their tools... ${ }^{70}$

Economy is the basis on which decisions must be made regarding people's free time and general morality:

Thus, I will state briefly my opinion about the Riga plays. I consider them to be expensive expenditures that disturb genuine contentment, do not promote permanent wellbeing and consume large amounts of money from the state. Or even in the case if they do not do this - they definitely cause the blood of the citizen to seethe feverishly, so that its circulation is excessively difficult and becomes hazardous to their health. [...] Thus, many a householder, many a lady would be spending their evenings at home in the bosom of their family, withdrawn into the peaceful satisfaction of their homes, caring for the wellbeing of their homes and children if a play did not take them away from their responsibilities. Many a young merchant would be spending his time safely at home reading, many a ladies' room would find more ideal and purer amenity dealing with useful handiwork, music or other fine arts, than undertaking the time-consuming preparations for a visit to the theatre,

70 Snell, Patriotische Unterhaltungen, 26-27. 
which would first require several hours and then several hours of sitting in one place, and thereafter waiting for the coachman, etc. ${ }^{71}$

Snell also bases his arguments in favour of the theatre on the principle of economy and joins Sulzer in his criticism of Teller, who sees no benefit in proper and pleasant pastimes:

Plays are a necessity of large cities, a fact that is so widely accepted today that no sovereign would leave this need unattended in his domain: not so much because of the enlightenment and good taste that it spreads, but upon the conviction that with the help of well-organised plays many an excess is prevented, the otherwise wasted time of many people is made useful and a lot of money is saved that would otherwise be spent on gambling or expensive pastimes, and thereby with a much smaller sacrifice that the people provide from their surplus to maintain the theatre, the general need for entertainments, relaxation and social life, which can so easily fall astray in large cities, is satisfied in a sensible way. ${ }^{72}$

Snell's Epicurus declares that rejoicing over the Creator's largess is a person's duty and natural urge and erring against it is to be ungrateful on the one hand and harmful on the other, and directs his defensive speech from work to justifying the joy and diversion you feel during your free time:

People require diversion at certain times - everyone feels this need, especially during the cold wintertime, when all of nature unites to suppress one's spirit. Where should a citizen of Riga find diversion at such a time? What means do you recommend for them to smooth the furrows on their brow, to shake off the dust, to bring joy to their hearts? What a sad appearance the city would take on if its only retreat were removed? Should the merchant who has time left over in the winter always sit in the company of books? And what should the man who spends his days with books and business affairs, documents and such do during the evenings? Sulk by himself? Or spend time with company that keeps him out until midnight so that he is not properly awake in the morning to do his day's work? For these people, a play is

71 Snell, Patriotische Unterhaltungen, 44.

72 Ibid., Patriotische Unterhaltungen, 51-52. 
an excellent refreshment: it frees the spirit from all the useless thoughts that have collected during the day, repels many a vexation from their emotions and sweeps away dark thoughts, it prepares the heart for the joyful enjoyment of a supper at home, ennobles the meal and makes the night's sleep sweeter. ${ }^{73}$

In Snell's case, the question is not so much the influence of the theatre but the management of time. From Snell's viewpoint, the theatre is not especially effective, so that one should not fear its very strong direct influence on society's educated elite or even the "young and the irrational". However, no special (educational or developmental) positive influence can be expected from it either. It is an entertaining luxury, and the main issue is whether there is any sense in spending resources (time and money) on it. Similarly, when theatrical activity is banned in the city of Tartu in the early $19^{\text {th }}$ century in connection with the reopening of the university, the main argument is related to sensible use of the academic family's time. Friedrich Maximilian Klinger, the curator of the University of Tartu and previously the author of Sturm und Drang, emphasises how important it is that a University of Tartu student becomes a proper citizen, scholar, school director and statesman for the development of his nation. The student's duty is to do his best in his studies and in these endeavours he must eliminate everything from his path that diverts him from this goal. Thus, the theatre is again cast in the role of misleader as was also alleged by the Pietists, but not because of its content and spontaneous effect, but rather the expenditure and waste of time involved. The arguments are of a purely economic nature, to which political circumstances were added - after the French Revolution great care had to be taken with all potential sources of unrest, in order to maintain stability and submissiveness in the society ${ }^{74}$

\section{IN CONCLUSION}

The discussions that took place during the early modern period about (performative) art involve questions about the changed religious situation, changing philosophical concepts and political circumstances. Above all, we can see how artistic depiction in the Protestant cultural

73 Ibid., 62-63.

74 Max Rieger, Friedrich Maximilian Klinger; sein Leben und Werke (Darmstadt: Arnold Bergsträsser, 1880), $592 \mathrm{ff}$. 
space initially became the object of religious criticism motivated by theology (incl. iconophobia), and thereafter, a philosophically motivated social-pedagogical assessment developed of art's relatively weak impact on the human character. The critical assessments of theatrical art culminate with economic arguments pro et contra of such activity.

Only some of the cases related to theatrical art are included in this article, and based thereon final conclusions cannot be drawn about how to regard artistic activity in the German cultural space in the late $18^{\text {th }}$ century. However, it is possible to make some initial observations.

During the $18^{\text {th }}$ century, art undoubtedly achieved some independence in regard to society and religion, to which it had been closely related earlier. At the end of the century theorists started to separate art from educational and moral goals. It could be said that art was relieved of its obligation to show the high-minded and good, and achieved some artistic freedom, to permit less than a hundred years later for the concept of l'art pour l'art to appear. As such art was separated from religion on the one hand and thereafter from the sphere of activities directly beneficial and necessary for society on the other. In certain sense, this development allowed art to be considered, from both a social and religious point of view, as a useless frippery and amusement, which can be ignored without suffering any damage.

In the examples included in the article, the assessment of art is closely related to what the goal of art was thought to be and to what extent this goal was thought to conform to religious and/or social goals. We get the impression that those who took art most seriously, were the ones who saw it as a part of a whole, which was directed at a common goal, i.e. for whom the goal of art was identical or similar with the goals aspired by religion or society. If a person's life and society as a whole has a goal - and in the $18^{\text {th }}$ century it was taken for granted that they did - then the assessment of art depends on how harmful, useless or beneficial it is for the achievement of this goal. 
Tima-Erika Friedenthal, Meelis Friedenthal: The Use and Abuse of Performative Arts for Religion and Society.

Keywords: Theatre, Enlightenment, Germany, Theology, Toleration, Criticism, Pietism

\section{SUMMARY:}

The objective of the article is to examine some of the discussions regarding performative arts (i.e. theatre) in Germany and the Baltic provinces in the $18^{\text {th }}$ century and to add theological-philosophical marginalia to those discussions. In the light of selected texts answers are sought for two main questions: 1) what place does sanctioned artistic activity have in the theological and intellectual atmosphaere in Germany? Does it largely coincide with social or religious goals like in the Middle Ages, or does it have some different purpose that is not overlapping with those of society or religion? 2) What benefit does society derive from artistic activity?

In $18^{\text {th }}$-century Germany, such issues were discussed in all the circles of society (ecclesiastic, artistic, educational, economic, etc.) thereby establishing a basis for aesthetics as a discipline related to art theory. If, in the early $18^{\text {th }}$ century, the German philosophers dealt with art historically or as subjected to other disciplines then by the end of the century, the arts had become independent. Current article traces through some discussions the arguments which were used in the conflicts regading the place of theatre in the society, and what expectations and assumptions accompanied these arguments. The authors have also sought a clearer understanding of the placement of theatre on the scale of beneficial-useless-harmful, based on the aims (related to society or religion) that have been stated by the proponents or assumed by default. The question's broader background includes an interest in how the reputation of theatre is connected to the goals assigned to it and how the corresponding trends compare with the reputation of religion in society.

In the examples included in the article, the assessment of any artistic activity is closely related to what the goal of art was thought to be and to what extent this goal was thought to conform to religious and/ or social goals. The article notices that those authors who took art most seriously, were the ones who saw it as a part of a whole. It is possible to distinguish between two groups of such authors: one for whom the goal of art was identical or similar with the goals aspired by religion or society and the other who saw theatrical performances as generally 
harmful or wasteful activity for society and thus dangerous. There emerges also a third group of authors what tends to regard theatre as (relatively) harmless, but at the same time accepts the limited usefulness of theatre for society and religion and accordingly theatre is often perceived as (mere) entertainment.

CV:

Tiina-Erika Friedenthal defended her MA thesis in 2012 in the theological faculty of the University of Tartu on the topic of "Parousia, fundamental experience of spiritual presence". The meaning and usage of the word 'parousia' in Antiquity, in Western Christianity, and in Martin Heidegger's philosophy was discussed in association with dramatic literature. Her PhD thesis in the Tartu University concerns the attitude and arguments against theatre during the long $18^{\text {th }}$ century $(1660-1830)$ in the German speaking cultural areas. Presently her research in the Georg-August-Universität Göttingen is supported by European Social Fund's Doctoral Studies and Internationalisation Programme DoRa, which is carried out by Foundation Archimedes.

Meelis Friedenthal defended his doctoral thesis about "The Tractatus moralis de oculo of the Tallinn City Archives" in the theological faculty of the Tartu University in 2008. In 2008 he joined Tartu University Library project dealing with intellectual history of the Baltic Sea region in the Early Modern period. From 2010 to 2013 he led a project dealing with the Early Modern Estonian book history. Meelis Friedenthal is currently Research Fellow in Lichtenberg-Kolleg - The Göttingen Institute of Advanced Study with the topic of religious toleration in the Early Modern period. 